Chapman University

Chapman University Digital Commons

Pharmacy Faculty Articles and Research

School of Pharmacy

2010

\title{
Synthesis and Evaluation of Conformationally Constrained Peptide Analogues as the Src SH3 Domain Binding Ligands
}

Rakesh Tiwari

Chapman University, tiwari@chapman.edu

Alex Brown

University of Rhode Island

Seetha Narramaneni

University of Rhode Island

Gongqin Sun

University of Rhode Island

Keykavous Parang

Chapman University, parang@chapman.edu

Follow this and additional works at: http://digitalcommons.chapman.edu/pharmacy_articles

Part of the Amino Acids, Peptides, and Proteins Commons, and the Medical Biochemistry Commons

\section{Recommended Citation}

Tiwari, Rakesh, et al. "Synthesis and evaluation of conformationally constrained peptide analogues as the Src SH3 domain binding ligands." Biochimie 92.9 (2010): 1153-1163. doi: 10.1016/j.biochi.2010.01.017

This Article is brought to you for free and open access by the School of Pharmacy at Chapman University Digital Commons. It has been accepted for inclusion in Pharmacy Faculty Articles and Research by an authorized administrator of Chapman University Digital Commons. For more information,

please contact laughtin@chapman.edu. 


\section{Synthesis and Evaluation of Conformationally Constrained Peptide Analogues as the Src SH3 Domain Binding Ligands}

\section{Comments}

NOTICE: this is the author's version of a work that was accepted for publication in Biochimie. Changes resulting from the publishing process, such as peer review, editing, corrections, structural formatting, and other quality control mechanisms may not be reflected in this document. Changes may have been made to this work since it was submitted for publication. A definitive version was subsequently published in Biochimie, volume 92, issue 9, in 2010. DOI: 10.1016/j.biochi.2010.01.017

The Creative Commons license below applies only to this version of the article.

\section{Creative Commons License}

\section{(c) 1 (1) 90}

This work is licensed under a Creative Commons Attribution-Noncommercial-No Derivative Works 4.0 License.

\section{Copyright}

Elsevier 


\section{Synthesis and Evaluation of Conformationally Constrained Peptide Analogues as the Src SH3 Domain Binding Ligands}

Rakesh Tiwari, ${ }^{\mathrm{a}}$ Alex Brown, ${ }^{\mathrm{b}}$ Seetha Narramaneni, ${ }^{\mathrm{b}}$ Gongqin Sun, ${ }^{\mathrm{b}}$ and Keykavous Parang ${ }^{\mathrm{a}, *}$

${ }^{a}$ Department of Biomedical and Pharmaceutical Sciences, College of Pharmacy, University of Rhode Island, Kingston, Rhode Island 02881, USA and ${ }^{\mathrm{b}}$ Department of Cell and Molecular Biology, University of Rhode Island, Kingston, Rhode Island 02881, USA.

*Corresponding author. 41 Lower College Road, Department of Biomedical and Pharmaceutical Sciences, College of Pharmacy, University of Rhode Island, Kingston, Rhode Island, 02881, USA; Tel.: +1-401-874-4471; Fax: +1-401-874-5787; E-mail address: kparang@uri.edu.

Keywords: c-Src, SH3 domain, VSL-12, peptide synthesis, conformationally constrained peptides, fluorescence polarization. 


\begin{abstract}
.
Src kinase activity is regulated by the interaction of SH3 domain with protein sequences that are rich in proline residues. Identification of more potent $\mathrm{SH} 3$ domain binding ligands that can regulate Src kinase activity is a subject of major interest. Conformationally constrained peptides have been previously used for improving the binding potency of the Src SH2 domain binding peptide ligands and peptide substrates of the substrate-binding site of Src. A series of peptide analogues of Ac-VSLARRPLPPLP $\left(\mathbf{1}\right.$, Ac-VSL-12, $\left.K_{\mathrm{d}}=0.34 \mu \mathrm{M}\right)$ were synthesized by introducing conformational constraints to improve the binding affinity towards the Src SH3 domain. Peptides synthesized through cyclization between $N$-terminal to $C$-terminal [VSLARRPLPPLP] or $N$-terminal to side chain flanking residues (i.e., $\left[{ }^{\beta}\right.$ AVS]LARRPLPPLP and [VSLE]RRPLPPLP) exhibited at least 6.4-fold less binding affinity $\left(K_{\mathrm{d}}=2.19-4.85 \mu \mathrm{M}\right)$ when compared to 1 . The data suggest upon $N$-terminal cyclization with $C$-terminal or flanking residues, the interactions of the amino acids in the core RPLPPLP reduce significantly with the residues within the Src SH3 domain. Conformationally constrained peptide V[SLARRPLPPLP] (5) was synthesized through cyclization of $C$-terminal to the serine side chain and displayed a comparable binding affinity $\left(K_{\mathrm{d}}=0.35 \mu \mathrm{M}\right)$ towards the Src SH3 domain versus that of $\mathbf{1}$. Thus, this template may be used to optimize and generate more potent analogues with higher stability.
\end{abstract}




\section{Introduction}

Protein tyrosine kinases (PTKs) catalyze the phosphorylation of specific tyrosine residues in proteins. Src, a member of nonreceptor tyrosine kinases, is involved in many cellular signaling pathways. Src contributes significantly in growth, differentiation, proliferation, development, and motility of many normal cell types [1]. Elevated levels of Src kinase activity are found in different cancer cells [2]. Thus, control or inhibition the Src kinase activity through chemical intervention has become a subject of major interest in drug discovery.

Src kinase contains an $N$-terminal unique domain that constitutes the Src homology (SH)4, followed by SH3 and SH2 regulatory domains, a kinase (catalytic) domain, and a $C$ terminal tail which includes a critical tyrosine residue (Tyr527). SH2 and SH3 regulatory domains mediate protein-protein interactions in cellular signaling cascades [3]. Specificity of interacting proteins and peptides with Src is determined by the chemical properties of the module binding surface of the Src SH3 and SH2 domains, which determines a preference for a common sequence with a range of variability. SH3 domains consist of approximately 60 amino acids and bind specifically to protein sequences that are rich in proline residues [4], whereas $\mathrm{SH} 2$ domains bind to protein sequences containing a phosphotyrosine residue [5].

The phosphorylation of the Tyr527 in Src by another PTK, Csk, leads to intramolecular binding of the SH2 domain to the $C$-terminal tail and inactivation of the enzyme (closed state) $[4,6]$. The Src SH3 domain stabilizes this state by interacting with the linker that connects the $\mathrm{SH} 2$ domain to the catalytic domain of the kinase. Src becomes active by autophosporylation of Tyr416 residue on the catalytic domain (open state) [7].

Src uses the SH3 domain to recruit numerous proteins which contain a polyproline motif such as Sam 68 [8], STAT3 [9], and p130cas [10,11]. A Src SH3 domain binding ligand can block the protein-protein interactions between Src and other proteins involved in signal transduction pathways.

Two classes of the Src SH3 binding ligands have been found that bind in opposite orientation. Classes I and II contain the consensus sequences of RXLPPXP and XPPLPXR, respectively [12]. The Src SH3 domain has a highly mobile and flexible region called RT loop containing arginine $(\mathrm{R})$ and threonine $(\mathrm{T})$ residues. RT loop is involved in interacting with the Src SH3 domain binding ligands. The binding capacity of both classes correlates on the positively-charged Arg residue of the ligands interacting with a negatively-charged residue in the RT loop of the Src SH3 domain. Classes I and II bind to the SH3 domain with the $N$-terminus or $C$-terminus of the ligand towards the RT loop, respectively.

Screening of the SH3 domain with c-DNA libraries, phage display, and biased peptide libraries has revealed a minimum recognition sequence, PLPPLP, for binding to the Src SH3 domain. Rickles et al. used biased phage display libraries to identify sequence RPLPPLP as the Src SH3 domain binding ligand with the $K_{\mathrm{d}}$ value of $17.7 \mu \mathrm{M}$ [13]. Addition of 5 more residues (VSLAR) flanking to the $N$-terminal of core ligand RPLPPLP generated peptide $\mathrm{V}_{1} \mathrm{~S}_{2} \mathrm{~L}_{3} \mathrm{~A}_{4} \mathrm{R}_{5} \mathrm{R}_{6} \mathrm{P}_{7} \mathrm{~L}_{8} \mathrm{P}_{9} \mathrm{P}_{10} \mathrm{~L}_{11} \mathrm{P}_{12}$ (VSL-12; $\left.K_{\mathrm{d}}=0.45 \mu \mathrm{M}\right)$ with an improved binding affinity of 39-fold versus the core ligand [14]. The structural complex of the ligand and the Src SH3 domain using NMR showed multiple interactions between the peptide residues in the core region and the Src SH3 domain [14].

Ferguson et al. showed a bivalent ligand strategy to increase binding between SEM-5 SH3 domain and its natural ligand. A conjugate of PPPVPPR and a cyclic peptide of 6 amino acid (formed by disulfide bonds between two cysteine residues) improved the binding affinity to 
SH3 domain by 1000-fold as compared to natural ligand [15]. Cyclization strategy has been commonly used in developing diagnostic and therapeutic peptidic and peptidomimetic agents [16-19]. Since peptides generally adopt highly flexible conformations in solution, a cyclization approach is used to reduce the conformational freedom of the molecules and improving binding affinity of specific conformation. Conformationally constrained structures become usually more selective in their affinity towards specific receptors and more stable towards proteases. In addition, cyclization often results in higher receptor binding affinity possibly by reducing unfavorable entropic effects [20].

We previously designed conformationally constrained peptides for improving the binding potency of SH2 domain binding peptide ligands [21] and peptide substrates of the substratebinding site of Src [22], demonstrating significantly higher binding affinity by cyclized peptides compared to the corresponding linear analogues. Herein, we investigated to determine whether the cyclization of the sequence in VSL-12 can enhance the binding affinity of the ligand to the SH3 domain. Three cyclization strategies, head to tail, $C$-terminal to side chain, and $N$-terminal to side chain, were used to synthesize conformationally constrained peptides (Fig. 1).

"Please insert Figure 1 here."

\section{Materials and Methods}

\subsection{Abbreviations}

Symbols and abbreviations for amino acids and peptides are in accord with the recommendations of the IUPAC-IUB Commission on Nomenclature (J. Biol. Chem. 1972, 247, 977). Other abbreviations used are: $\mathrm{AcOH}$, acetic acid; Boc, tert-butyloxycarbonyl; $t \mathrm{Bu}$, tert-butyl; DIC, $N, N^{\prime}$-diisopropylethylcarbodiimide; DIPEA, $N, N$-diisopropylethylamine; Dmab, 4-[[1-(4,4dimethyl-2,6-dioxocyclohexylidene)-3-methylbutyl]amino]phenyl]methyl] ester); Flu, 5(6)carboxyfluorescein; Fmoc, $N$-(9-fluorenyl)methoxycarbonyl; HBTU, 2-(1H-benzotriazole-1-yl)1,1,3,3-tetramethyluronium hexafluorophosphate); HOAt, 1-hydroxy-7-azabenzotriazole; HOBt, 1-hydroxybenzotriazole; Mtt, 4-methyltrityl; NMM, N-methylmorpholine; Pbf, (2,2,4,6,7pentamethyldihydrobenzofuran-5-sulfonyl); 2-PhiPr, 2-phenylisopropyl; PyAOP, 7azabenzotriazol-1-yloxy-tripyrrolidinophosphonium hexafluorophosphate; SELDI-TOF, surfaceenhanced laser desorption/ionization time-of-flight; $t \mathrm{Bu}$, tert-butyl; trt, trityl; TFA, trifluoroacetic acid; TIS, triisopropylsilane. .

\subsection{Materials}

All reagents used for bacterial culture and protein expression were purchased from Fisher Scientific. Glutathione S transferase (GST) was purchased from Sigma-Aldrich Chemical Co (Milwaukee, WI). All the reagents for peptide synthesis were purchased from the Novabiochem. Fmoc-amino acids, H-Pro-2-chlorotrityl chloride resin, coupling reagents, and Fmoc-amino acid building blocks were purchased from Novabiochem. Other chemicals and reagents were purchased from Sigma-Aldrich Chemical Co. (Milwaukee, WI).

\subsection{General}


All reactions were carried out in Bio-Rad polypropylene columns by shaking and mixing using a Glass Col small tube rotator in dry conditions or on a PS3 automated peptide synthesizer (Rainin Instrument Co., Inc.) at room temperature unless otherwise stated. In general, all peptides were synthesized by the solid-phase synthesis strategy employing Fmoc-based chemistry and Fmoc-L-amino acid building blocks. HBTU and DIPEA in DMF were used as coupling and activating reagents, respectively. Fmoc-deprotection at each step was carried out in the presence of piperidine in DMF two times (20\% v/v, 10x volume as compared with resin) followed by washing with DMF. Final cleavage of the peptides from the solid support was achieved by using reagent $\mathrm{R}$ (TFA/thioanisole/1,2-ethanedithiol/anisole 90:5:3:2 v/v/v/v, volume $5 \mathrm{x}$ compared to dried resin) for $2 \mathrm{~h}$. Crude peptides were precipitated by addition of cold diethyl ether $\left(\mathrm{Et}_{2} \mathrm{O}\right)$, separated, washed by centrifugation (washed with diethyl ether, $3 \times 50 \mathrm{~mL}$ and centrifuged at $4000 \mathrm{rpm}$ for $5 \mathrm{~min}$ ), and were purified by preparative reverse-phase HPLC (Shimadzu LC-8A preparative liquid chromatograph) on a Phenomenex-Gemini C18 column (10 $\mu \mathrm{m}, 250 \times 21.2 \mathrm{~mm})$. The peptides were separated by eluting the crude peptide at $12.0 \mathrm{~mL} / \mathrm{min}$ using a gradient of 5-65\% acetonitrile (0.1\% TFA) and water ( $0.1 \%$ TFA) over 60 min, and then, they were lyophilized. Chromatograms were recorded at $220 \mathrm{~nm}$ using a UV detector. The purity of final products $(>95 \%)$ was confirmed by HPLC. The chemical structures of compounds were determined by a SELDI-TOF mass spectrometer on a Ciphergen protein chip instrument using $\alpha$ cyano-4-hydroxycinnamic as a matrix. Details of procedures are presented below. All of the amino acids in $A c-V_{1} S_{2} L_{3} A_{4} R_{5} R_{6} P_{7} L_{8} P_{9} P_{10} L_{11} P_{12}$ (1) were numbered on the basis of their positions relative to the $N$-terminal valine residue (V1).

\subsubsection{Peptide Synthesis}

\subsubsection{Ac- $V_{1} S_{2} L_{3} A_{4} R_{5} R_{6} P_{7} L_{8} P_{9} P_{10} L_{11} P_{12}$ (Ac-VSL-12, 1 ) and Fluorescein-}

VSLARRPLPPLP (2, Flu-VSL-12). H-Pro-2-chlorotrityl chloride resin (11, $0.91 \mathrm{~g}, 0.40 \mathrm{mmol}$, $0.44 \mathrm{mmol} / \mathrm{g}$ ) was swollen under dry nitrogen using anhydrous DMF for about $15 \mathrm{~min}$. The excess of the solvent was filtered off. The swelling and filtration steps were repeated for 2 more times before the coupling reactions. Fmoc-Leu-OH $(1.47 \mathrm{~g}, 4.16 \mathrm{mmol})$ was coupled to the $N$ terminal of proline-trityl resin using HBTU $(1.52 \mathrm{~g}, 4.0 \mathrm{mmol})$ and DIPEA $(1.45 \mathrm{~mL}, 8.8 \mathrm{mmol})$ in DMF ( $5 \mathrm{~mL}$ ) by mixing for $1.5 \mathrm{~h}$. After the coupling was completed (confirmed by Kaiser test), the reaction solution was filtered off and the resin was collected by filtration and washed with DMF $(7 \times 25 \mathrm{~mL})$, followed by Fmoc-deprotection using piperidine in DMF $(20 \% \mathrm{v} / \mathrm{v}, 25$ $\mathrm{mL}, 2$ times, $5 \mathrm{~min}$ and $10 \mathrm{~min})$. The resin was washed with DMF $(7 \times 25 \mathrm{~mL})$. The subsequent amino acids, Fmoc-Pro-OH, Fmoc-Pro-OH, Fmoc-Leu-OH, Fmoc-Pro-OH, Fmoc-Arg(Pbf)-OH, Fmoc-Arg(Pbf)-OH, Fmoc-Ala-OH, Fmoc-Leu-OH, Fmoc-Ser(OtBu)-OH, and Fmoc-Val-OH, respectively, were coupled in a similar manner. Fmoc-deprotection at $N$-terminal was carried out in the presence of piperidine in DMF $(20 \% \mathrm{v} / \mathrm{v}, 25 \mathrm{~mL}, 2 \times 10 \mathrm{~min})$ to afford 12 . The resin was collected by filtration and washed with DMF $(10 \times 25 \mathrm{~mL})$. Resin 12 was divided into two portions, each with $0.2 \mathrm{mmol}$ scale: (1) To the first portion of the resin $(0.2 \mathrm{mmol})$ was added $\mathrm{Ac}_{2} \mathrm{O}(945 \mu \mathrm{L}, 10 \mathrm{mmol})$ and DIPEA $(1.74 \mathrm{~mL}, 10.6 \mathrm{mmol})$ in DMF $(6 \mathrm{~mL})$. The mixture was shaken at room temperature for $45 \mathrm{~min}$. (2) The second portion of resin 12 was labeled with carboxyfluoresceine at $N$-terminal. 5(6)-Carboxyfluorescein $(0.38 \mathrm{~g}, 1 \mathrm{mmol})$ was preactivated with PyAOP (0.52 g, $1 \mathrm{mmol})$ and DIPEA $(0.35 \mathrm{~mL}, 2.1 \mathrm{mmol})$ in DCM/DMF (1:9 v/v, $5 \mathrm{~mL})$ for $10 \mathrm{~min}$ and was added to the second portion of resin 12. The mixture was shaken at room temperature for $3.5 \mathrm{~h}$. The completion of the coupling was monitored by Kaiser test. The excess 
of the reagents were washed with DMF $(10 \times 25 \mathrm{~mL})$. Both portions were washed with DMF, DCM, DMF-MeOH, and $\mathrm{MeOH}$, respectively (each with $2 \times 25 \mathrm{~mL}$ ) to remove the remaining of reagents and impurities, The resins were dried in vacuum for $24 \mathrm{~h}$. Freshly prepared cleavage cocktail, reagent R, TFA/thioanisole/1,2-ethanedithiol/anisole (90:5:3:2 v/v/v/v, $10 \mathrm{~mL}$ ), was added to the resins. The mixtures were shaken at room temperature for $2 \mathrm{~h}$. The resins were collected by filtration and washed with another $2 \mathrm{~mL}$ of cleavage cocktail. Combined filtrates were evaporated to a minimum volume under dry nitrogen. After precipitation in $\mathrm{Et}_{2} \mathrm{O}$, the crude peptides were lyophilized and purified by using a semi-preparative reverse-phase HPLC. AcVSL-12 (1): SELLDI-TOF (m/z) [ $\left.\mathrm{C}_{63} \mathrm{H}_{108} \mathrm{~N}_{18} \mathrm{O}_{15}\right]$ : calcd., 1356.82; found 1357.79, $[\mathrm{M}+\mathrm{H}]^{+}$, $1380.69[\mathrm{M}+\mathrm{Na}]^{+}$. Flu-VSL12 (2): SELDI-TOF $(\mathrm{m} / \mathrm{z})\left[\mathrm{C}_{82} \mathrm{H}_{118} \mathrm{~N}_{18} \mathrm{O}_{20}\right]$ : calcd., 1674.88; found, $1675.82[\mathrm{M}+\mathrm{H}]^{+}, 1697.87[\mathrm{M}+\mathrm{Na}]^{+}$.

2.3.1.2. [VSLARRPLPPLP] (3, head to tail cyclization). The linear peptide was assembled on the H-Pro-2-chlorotrityl chloride resin $(\mathbf{1 1}, 0.44 \mathrm{mmol} / \mathrm{g})$ in $0.41 \mathrm{mmol} \mathrm{scale}$ as described above. After the final deprotection of the $N$-terminal Fmoc group, the protected peptide was cleaved from trityl resin 12 in the presence of the cleavage cocktail AcOH/TFE/DCM (1:2:7 v/v/v, 40 $\mathrm{mL}$ ) for $1 \mathrm{~h}$ at room temperature to yield 13. The resin was collected by filtration and washed with TFE/DCM $(2: 8 \mathrm{v} / \mathrm{v}, 2 \times 10 \mathrm{~mL})$. The combined filtrates were evaporated in vacuum. To the residue was added hexane $(2 \times 25 \mathrm{~mL})$ to remove the acetic acid from the mixture. The crude protected peptide was dried in vacuum overnight. Examining a small portion of the crude showed a major peak of the protected peptide by the HPLC. Thus, the crude was used directly for the cyclization. The dried crude linear protected peptide was dissolved in the DMF/DCM (5:1 v/v, $60 \mathrm{~mL}$ ). HOAt (223 mg, $1.64 \mathrm{mmol}, 4$ equiv) and DIC (290 $\mu \mathrm{L}, 1.86 \mathrm{mmol}, 4.5$ equiv.) were added to the mixture and the solution was stirred for $4 \mathrm{~h}$. After completion of the cyclization, as shown by the SELDI-TOF, the solvents were removed under reduced pressure on a rotary evaporator. The crude cyclic protected peptide was dried overnight in vacuum before the final cleavage. Freshly prepared cleavage cocktail, reagent R, TFA/thioanisole/1,2ethanedithiol/anisole $(90: 5: 3: 2 \mathrm{v} / \mathrm{v} / \mathrm{v} / \mathrm{v}, 10 \mathrm{~mL})$ was added to dried the cyclic protected peptide. The mixture was stirred at room temperature for $2 \mathrm{~h}$. The cleavage cocktail was concentrated to a minimum volume under reduced pressure by a rotary evaporator. After precipitation of crude peptide in cold $\mathrm{Et}_{2} \mathrm{O}$ and centrifugation, the crude peptide was lyophilized and purified by using a semi-preparative reverse-phase HPLC. SELLDI-TOF (m/z) $\left[\mathrm{C}_{61} \mathrm{H}_{104} \mathrm{~N}_{18} \mathrm{O}_{13}\right]$ : calcd., 1296.80; found, $1297.91[\mathrm{M}+\mathrm{H}]^{+}, 1320.12[\mathrm{M}+\mathrm{Na}]^{+}, 1336.01[\mathrm{M}+\mathrm{K}]^{+}$.

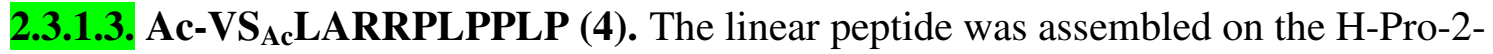
chlorotrityl chloride resin $(\mathbf{1 1}, 0.45 \mathrm{~g}, 0.20 \mathrm{mmol}, 0.44 \mathrm{mmol} / \mathrm{g})$ on a PS3 automated peptide synthesizer. HBTU (4 equiv) and NMM (0.40 M) in DMF were used as coupling and activating reagents. Piperidine in DMF (20\% v/v) was used as the deprotecting reagent. The sequence was assembled using double coupling with Fmoc-Amino Acid-OH building blocks (4 equiv.) as compared to the resin. The building block used in the synthesis were Fmoc-Leu-OH, Fmoc-Pro$\mathrm{OH}$, Fmoc-Pro-OH, Fmoc-Leu-OH, Fmoc-Pro-OH, Fmoc-Arg(Pbf)-OH, Fmoc-Arg(Pbf)-OH, Fmoc-Ala-OH, Fmoc-Leu-OH, Fmoc-Ser(OTrt)-OH, and Fmoc-Val-OH, respectively. Deprotection of the Fmoc group at $N$-terminal of the sequence with piperidine in DMF (20\% v/v) afforded 14. A small portion of the resin was cleaved. The crude was used for confirming the molecular weight by SELDI-TOF indicating the presence of the linear sequence. The resinattached peptide was mixed with the cleavage cocktail (TFA/DCM/TIS, 1:94:5 v/v/v) $(4 \times 15$ 
$\mathrm{mL}, 10 \mathrm{~min}$.) under mild conditions. The resin was collected by filtration and washed with dry DCM $(5 \times 25 \mathrm{~mL})$. Collected combined filtrates were evaporated under reduced pressure. Partially protected peptide was dried in vacuum and was treated with $\mathrm{Ac}_{2} \mathrm{O}(945 \mu \mathrm{L}, 10 \mathrm{mmol})$ in DMF $(6 \mathrm{~mL})$ in the presence of DIPEA $(1.74 \mathrm{~mL}, 10.6 \mathrm{mmol})$ at room temperature for $30 \mathrm{~min}$. The solvents were removed under reduced pressure on a rotary evaporator and the crude protected peptide was dried overnight before the final cleavage. Freshly prepared cleavage cocktail, TFA/thioanisole/1,2-ethanedithiol/anisole (90:5:3:2 v/v/v/v, $10 \mathrm{~mL})$ was added to the mixture and the solution was stirred at the room temperature for $2 \mathrm{~h}$. The excess of the solvents were removed under reduced pressure using a rotary evaporator. After precipitation of the crude peptide in cold $\mathrm{Et}_{2} \mathrm{O}$ and centrifugation, the crude peptide was lyophilized and purified by using a semi-preparative reverse-phase HPLC. SELLDI-TOF (m/z) $\left[\mathrm{C}_{61} \mathrm{H}_{104} \mathrm{~N}_{18} \mathrm{O}_{13}\right]$ : calcd., 1367.84; found, $1368.81[\mathrm{M}+\mathrm{H}]^{+}, 1391.03[\mathrm{M}+\mathrm{Na}]^{+}, 1406.72[\mathrm{M}+\mathrm{K}]^{+}$.

2.3.1.4. V[SLARRPLPPLP] (5, $\boldsymbol{C}$-terminal to side chain cyclization). The linear peptide was assembled on H-Pro-2-chlorotrityl chloride resin $(\mathbf{1 1}, 0.91 \mathrm{~g}, 0.40 \mathrm{mmol}, 0.44 \mathrm{mmol} / \mathrm{g}$ ) as described above on a PS3 automated peptide synthesizer. Boc-Val-OH was used in place of the regular Fmoc-Val-OH at position 1. After assembling the linear peptide chain, using building blocks Fmoc-Leu-OH, Fmoc-Pro-OH, Fmoc-Pro-OH, Fmoc-Leu-OH, Fmoc-Pro-OH, Fmoc$\operatorname{Arg}(\mathrm{Pbf})-\mathrm{OH}$, Fmoc-Arg(Pbf)-OH, Fmoc-Ala-OH, Fmoc-Leu-OH, Fmoc-Ser(OTrt)-OH, and Boc-Val-OH, a small portion of the resin was cleaved, and the molecular weight was confirmed by SELDI-TOF. The resin-attached peptide was mixed with the cleavage cocktail, TFA/DCM/TIS $(1: 94: 5 \mathrm{v} / \mathrm{v} / \mathrm{v}, 5 \times 25 \mathrm{~mL}, 10 \mathrm{~min}$.) to deprotect the trityl group from the side chain of the serine and to cleave the partially protected peptide from the resin to afford $\mathbf{1 5}$. The resin was collected by filtration and was washed with dry DCM $(5 \times 25 \mathrm{~mL})$. The combined filtrates were evaporated under reduced pressure. The partially protected crude peptide was dried in vacuum overnight. A small portion of the crude showed a major peak of protected peptide by HPLC. Thus, the crude was used directly for the cyclization. The crude peptide was dried and dissolved in DMF/DCM (5:1 v/v, $60 \mathrm{~mL})$. HOBt (109 mg, $0.8 \mathrm{mmol})$, HBTU (303 mg, 0.8 mmol), DIC (125 $\mu \mathrm{L}, 0.8 \mathrm{mmol})$, and DIPEA $(697 \mu \mathrm{L}, 4.2 \mathrm{mmol})$ were added to the solution. The mixture was stirred slowly at room temperature for $8 \mathrm{~h}$. After completion of the cyclization, as shown by SELDI-TOF, the solvents were removed on a rotary evaporator. The crude cyclic protected peptide was dried overnight in vacuum before the final cleavage. Freshly prepared cleavage cocktail, reagent $\mathrm{R}$, TFA/thioanisole/1,2-ethanedithiol/anisole (90:5:3:2 v/v/v/v, 10 $\mathrm{mL}$ ), was added to dried cyclic protected peptide. The mixture was stirred at room temperature for $2 \mathrm{~h}$. After $2 \mathrm{~h}$, the cleavage cocktail was concentrated under reduced pressure to minimum volume by a rotary evaporator. After precipitation of the crude peptide in cold $\mathrm{Et}_{2} \mathrm{O}$ and centrifugation, the crude peptide was lyophilized and purified by using a semi-preparative reverse-phase HPLC. SELDI-TOF $(\mathrm{m} / \mathrm{z})\left[\mathrm{C}_{61} \mathrm{H}_{104} \mathrm{~N}_{18} \mathrm{O}_{13}\right]$ : calcd., 1296.80; found 1297.92 [M + $\mathrm{H}]^{+}, 1320.13[\mathrm{M}+\mathrm{Na}]^{+}, 1336.02[\mathrm{M}+\mathrm{K}]^{+}$.

2.3.1.5. [ ${ }^{\beta}$ AVS]LARRPLPPLP $(6, N$-terminal to side chain cyclization $)$. The linear peptide was synthesized on a PS3 automatic peptide synthesizer as described above using Fmoc-ProWang resin (16, $0.35 \mathrm{mmol}, 0.51 \mathrm{mmol} / \mathrm{g})$. HBTU (4 equiv) and NMM (0.37 M) in DMF were used as coupling and activating reagents. Piperidine in DMF (20\% v/v) was used as the deprotecting reagent. The sequence was assembled using double coupling with Fmoc-Amino Acid-OH building blocks (4 equiv.) as compared to the resin. The building block used in the synthesis were Fmoc-Leu-OH, Fmoc-Pro-OH, Fmoc-Pro-OH, Fmoc-Leu-OH, Fmoc-Pro-OH, 
Fmoc-Arg(Pbf)-OH, Fmoc-Arg(Pbf)-OH, Fmoc-Ala-OH, Fmoc-Leu-OH, Fmoc-Ser(OTrt)-OH, Fmoc-Val-OH, and Fmoc- $\beta$-Ala-OH, respectively. After deprotection of the Fmoc group at the end of $N$-terminal of the sequence with piperidine in DMF $(20 \% \mathrm{v} / \mathrm{v})$, a small portion of the resin was cleaved and the molecular weight of the peptide was confirmed by SELDI-TOF. The trityl group from the side chain of the serine was removed under mild conditions (TFA/DCM/TIS, 1:94:5 v/v/v, $30 \mathrm{~mL}, 4 \times 10 \mathrm{~min}$.) to yield 17 . The resin was collected by filtration and was washed with dry DCM $(5 \times 50 \mathrm{~mL})$. The resin was dried in vacuum for $30 \mathrm{~min}$. To the resinattached peptide was added, DMF/DCM (60 mL, 5:1 v/v), HOAt (190.5 mg, $1.4 \mathrm{mmol}, 4$ equiv), and DIC ( $245 \mu \mathrm{L}, 1.57 \mathrm{mmol}, 4.5$ equiv) and the mixture was shaken at room temperature for 8 h. The completion of cyclization was confirmed by Kaiser test as well as by SELDI-TOF. The resin was collected by filtration. After washing the resin by DMF, DCM, and $\mathrm{MeOH}$, respectively (each $5 \times 30 \mathrm{~mL}$ ), the resin was dried in vacuum for $24 \mathrm{~h}$. Freshly prepared cleavage cocktail, reagent $\mathrm{R}$, TFA/thioanisole/1,2-ethanedithiol/anisole (90:5:3:2 v/v/v/v, $12 \mathrm{~mL}$ ), was added to dried resin-attached peptide. The mixture was shaken at room temperature for $2 \mathrm{~h}$. After filtration, the filtrate was concentrated to a minimum volume under reduced pressure by a rotary evaporator. After precipitation of the crude peptide in cold $\mathrm{Et}_{2} \mathrm{O}$ and centrifugation, the crude peptide was lyophilized and purified by using semi-preparative reverse-phase HPLC. SELDITOF (m/z) [ $\left.\mathrm{C}_{61} \mathrm{H}_{104} \mathrm{~N}_{18} \mathrm{O}_{13}\right]$ : calcd., 1367.84; found, $1368.81[\mathrm{M}+\mathrm{H}]^{+}, 1391.03[\mathrm{M}+\mathrm{Na}]^{+}$, $1406.71[\mathrm{M}+\mathrm{K}]^{+}$

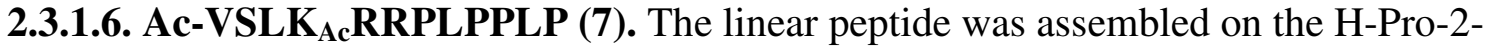
chlorotrityl chloride resin $(\mathbf{1 1}, 0.45 \mathrm{~g}, 0.20 \mathrm{mmol}, 0.44 \mathrm{mmol} / \mathrm{g})$ as described above on a PS3 automated peptide synthesizer. Fmoc-Lys (Mtt)-OH was used in place of Fmoc-Ala-OH at position 4. Assembling of the linear peptide chain was carried out using building blocks, FmocLeu-OH, Fmoc-Pro-OH, Fmoc-Pro-OH, Fmoc-Leu-OH, Fmoc-Pro-OH, Fmoc-Arg(Pbf)-OH, Fmoc-Arg(Pbf)-OH, Fmoc-Lys (Mtt)-OH, Fmoc-Leu-OH, Fmoc-Ser(OtBu)-OH, and Fmoc-Val$\mathrm{OH}$, respectively. After deprotection of the Fmoc group at the end of $N$-terminal of the sequence, a small portion of resin $\mathbf{1 8}$ was cleaved. The crude was monitored with SELDI-TOF confirming the molecular weight of the linear sequence. Resin $\mathbf{1 8}$ was mixed with the cleavage cocktail, (TFA/DCM/TIS) $(2: 93: 5 \mathrm{v} / \mathrm{v} / \mathrm{v}, 15 \mathrm{~mL}, 5 \times 15 \mathrm{~min}$.), to deprotect the Mtt group from the side chain of the lysine and to cleave the partially protected peptide from the resin. The resin was collected by filtration and was washed with dry DCM $(5 \times 25 \mathrm{~mL})$. Collected combined filtrates were evaporated in vacuum. The partially protected peptide was dried in vacuum and was treated with $\mathrm{Ac}_{2} \mathrm{O}(945 \mu \mathrm{L}, 10 \mathrm{mmol})$ and DIPEA $(1.74 \mathrm{~mL}, 10 \mathrm{mmol})$ in DMF $(6 \mathrm{~mL})$. The mixture was shaken at room temperature for $30 \mathrm{~min}$. The solvents were removed under reduced pressure on a rotary evaporator and the crude was dried overnight before the final cleavage. Freshly prepared cleavage cocktail, TFA/thioanisole/1,2-ethanedithiol/anisole (90:5:3:2 v/v/v/v, $10 \mathrm{~mL})$, was added to the crude and the mixture was stirred at the room temperature for $2 \mathrm{~h}$. The excess of the solvent was removed using a rotary evaporator. After precipitation of the crude peptide in cold $\mathrm{Et}_{2} \mathrm{O}$, and centrifugation, the crude peptide was lyophilized and purified by using a semipreparative reverse-phase HPLC. SELDI-TOF (m/z) for $\left[\mathrm{C}_{68} \mathrm{H}_{117} \mathrm{~N}_{19} \mathrm{O}_{16}\right]$ : calcd, 1455.89; found, $1456.61[\mathrm{M}+\mathrm{H}]^{+}, 1478.90[\mathrm{M}+\mathrm{Na}]^{+}, 1494.81[\mathrm{M}+\mathrm{K}]^{+}$.

2.3.1.7. VSL[KRRPLPPLP] (8, $\boldsymbol{C}$-terminal to side chain cyclization). The linear peptide was assembled on H-Pro-2-chlorotrityl chloride resin $(\mathbf{1 1}, 0.91 \mathrm{~g}, 0.40 \mathrm{mmol}, 0.44 \mathrm{mmol} / \mathrm{g})$ as described above on a PS3 automated peptide synthesizer. Fmoc-Lys(Mtt)-OH and Boc-Val-OH 
were used in place of Fmoc-Ala-OH and Fmoc-Val-OH at positions 1 and 4, respectively. The peptide assembly was carried out using building blocks Fmoc-Leu-OH, Fmoc-Pro-OH, FmocPro-OH, Fmoc-Leu-OH, Fmoc-Pro-OH, Fmoc-Arg(Pbf)-OH, Fmoc-Arg(Pbf)-OH, Fmoc-Lys $(\mathrm{Mtt})-\mathrm{OH}$, Fmoc-Leu-OH, Fmoc-Ser $(\mathrm{O} t \mathrm{Bu})-\mathrm{OH}$, and Boc-Val-OH to yield 19. After completion of the sequence, a small portion of the resin was cleaved. The crude showed the molecular weight of the linear sequence using SELDI-TOF. Resin 19 was mixed with the cleavage cocktail, TFA/DCM/TIS (2:93:5 v/v/v, $15 \mathrm{~mL}, 5 \times 15 \mathrm{~min}$.), to deprotect the Mtt group from the side chain of the lysine and to cleave the partially protected peptide from the resin to yield $\mathbf{2 0}$. The resin was washed with dry DCM $(5 \times 25 \mathrm{~mL})$ and collected combined filtrates were evaporated under reduced pressure. After drying the partial protected crude peptide, the cyclization of the side chain with the $C$-terminal was achieved in the solution phase. The crude was dried and dissolved in DMF/DCM (5:1 v/v, $60 \mathrm{~mL})$. HOAt $(223 \mathrm{mg}, 1.64 \mathrm{mmol})$ and DIC $(290 \mu \mathrm{L}, 1.86$ $\mathrm{mmol}$ ) were added and the mixture was stirred for $8 \mathrm{~h}$. After completion of the cyclization, as shown by the SELDI-TOF, the solvents were removed on a rotary evaporator. The crude cyclic protected peptide was dried overnight before the final cleavage. Freshly prepared cleavage cocktail reagent $\mathrm{R}$, TFA/thioanisole/1,2-ethanedithiol/anisole (90:5:3:2 v/v/v/v, $10 \mathrm{~mL}$ ), was added to dried cyclic protected peptide. The solution was stirred at room temperature for $2 \mathrm{~h}$. The cleavage cocktail was concentrated to a minimum volume under reduced pressure by using a rotary evaporator. After precipitation of the crude peptide in cold $\mathrm{Et}_{2} \mathrm{O}$, and centrifugation, the crude peptide was lyophilized and purified by using a semi-preparative reverse-phase HPLC. SELDI-TOF $(\mathrm{m} / \mathrm{z})$ for $\left[\mathrm{C}_{61} \mathrm{H}_{104} \mathrm{~N}_{18} \mathrm{O}_{13}\right]$ : calcd., 1354.70; found, $1356.11[\mathrm{M}+\mathrm{H}]^{+}, 1378.31[\mathrm{M}+$ $\mathrm{Na}]^{+}, 1393.70[\mathrm{M}+\mathrm{K}]^{+}$.

2.3.1.8. VSLERRPLPPLP (9) and [VSLE]RRPLPPLP (10, $N$-terminal to side chain cyclization). The linear peptide was assembled on H-Pro-2-chlorotrityl chloride resin (11, 0.91 $\mathrm{g}, 0.40 \mathrm{mmol}, 0.44 \mathrm{mmol} / \mathrm{g}$ ) as described above on a PS3 automated peptide synthesizer. FmocGlu(ODmab)-OH was used in the place of Fmoc-Ala-OH at position 4. The Fmoc group of the $N$-terminal was removed with piperidine (20\%) to yield 21. The Dmab group from the side chain of the glutamic acid was removed using hydrazine hydrate in DMF (2\%, $3 \times 25 \mathrm{~mL})$ for $10 \mathrm{~min}$ to afford 22. The resin-attached peptide was washed with the excess of the solvents, DMF, DCM, and DMF, respectively (each $3 \times 35 \mathrm{~mL}$ ) and was dried in vacuum overnight. The resin was divided into two portions. The first portion was used for the synthesis of the linear peptide by cleavage using reagent $\mathrm{R}$ to yield $\mathbf{9}$ as described below. The second part of $\mathbf{2 2}$ was used for the cyclization between $\mathrm{N}$-terminal and the $\mathrm{COOH}$ group of the side chain of glutamic acid. The resin was swollen in the dry DMF under nitrogen. The excess of solvent was removed and to the resin was added DMF/DCM (5:1 v/v, $60 \mathrm{~mL})$, HOAt $(112 \mathrm{mg}, 0.82 \mathrm{mmol})$, and DIC $(145 \mu \mathrm{L}$, $9.3 \mathrm{mmol})$. The mixture was agitated for $12 \mathrm{~h}$ at room temperature. After completion of the cyclization, as shown by SELDI-TOF by cleavage of a few resin beads, the solvents were removed by filtration. The resin was washed with excess of solvents, DMF, DCM, and MeOH (3 $\times 35 \mathrm{~mL}$, each), respectively, and dried in vacuum overnight. Freshly prepared cleavage cocktail, TFA/thioanisole/1,2-ethanedithiol/anisole (90:5:3:2 v/v/v/v, $10 \mathrm{~mL})$, was added to dried cyclic and linear peptide resins and the mixture was shaken at room temperature for $2 \mathrm{~h}$. The resins were collected by filtration and washed with another $2 \mathrm{~mL}$ of cleavage cocktail. Combined filtrates of both peptides were evaporated in separate flask to a minimum volume amount under dry nitrogen. After precipitation of the crude peptide in cold $\mathrm{Et}_{2} \mathrm{O}$, and centrifugation, the crude peptide was lyophilized and purified by using semi-preparative reverse-phase HPLC. 9: SELDI- 
TOF (m/z) for $\left[\mathrm{C}_{63} \mathrm{H}_{108} \mathrm{~N}_{18} \mathrm{O}_{16}\right]$ : calcd., 1372.82; found, $1374.0[\mathrm{M}+\mathrm{H}]^{+} ; 1395.91[\mathrm{M}+\mathrm{Na}]^{+}$. 10: SELDI-TOF $(\mathrm{m} / \mathrm{z})$ for $\left[\mathrm{C}_{61} \mathrm{H}_{104} \mathrm{~N}_{18} \mathrm{O}_{13}\right]$; calcd., 1355.63; found, $1356.64[\mathrm{M}+\mathrm{H}]^{+} ; 1378.70$ $[\mathrm{M}+\mathrm{Na}]^{+}$.

\subsubsection{SH3 domain protein purification. The Chicken Src SH3 domain was expressed as a} glutathione $S$-transferase fusion protein in $E$. coli DH5 $\alpha$ cells using the plasmid pGEX-4T1. Upon sequence verification, a $500 \mathrm{~mL}$ culture of cells in LB and ampicillin were grown at $37{ }^{\circ} \mathrm{C}$ while shaking at $250 \mathrm{rpm}$. When an $\mathrm{OD}_{600}$ of about 0.6 was achieved, the culture was diluted with another $500 \mathrm{~mL}$ of fresh LB and ampicillin and expression was induced with $400 \mu \mathrm{M}$ IPTG. The induction was for $8 \mathrm{~h}$ at $250 \mathrm{rpm}$ and $20^{\circ} \mathrm{C}$. Harvesting of the cells by centrifugation was followed by freeze-thaw cycle and re-suspension in fresh PBS buffer $\mathrm{pH}$ 7.4. The cells were then sonicated and the lysate was cleared by centrifugation. The lysate was incubated for a period of one hour with approximately $1 \mathrm{~mL}$ glutathione-agarose at $4{ }^{\circ} \mathrm{C}$. This lysate was then passed

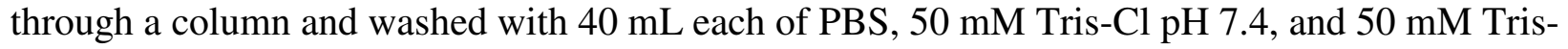
$\mathrm{Cl} \mathrm{pH} \mathrm{8.0.} \mathrm{The} \mathrm{elution} \mathrm{of} \mathrm{purified} \mathrm{GST-Src} \mathrm{SH3} \mathrm{fusion} \mathrm{protein} \mathrm{was} \mathrm{then} \mathrm{carried} \mathrm{out} \mathrm{with} 10 \mathrm{mM}$ reduced glutathione in $50 \mathrm{mM}$ Tris $\mathrm{pH}$ 8.0. All buffers used were chilled and $0.1 \% \beta$ mercaptoethanol was added fresh prior to use. Eluted fractions were qualified and quantified by Bradford assay and SDS-PAGE, respectively (Fig. 2). These fractions, ranging from 2.25 to 7.50 $\mathrm{g} / \mathrm{L}$ in concentration, were aliquoted and stored in the elution buffer at $-20^{\circ} \mathrm{C}$

\section{"Please insert Figure 2 here."}

\subsubsection{Fluorescence polarization assay}

To determine the binding of VSL12 towards the Src SH3 domain, fluorescein-labeled VSL12 was synthesized and purified by HPLC as described above. The fluorescence polarization (FP) binding assay was carried out as described previously [23]. Flu-VSL12 (120 nM) was kept constant in the presence of increasing SH3 domain concentration in $50 \mathrm{mM}$ Tris pH 8.0 buffer. FP was then detected using a PerkinElmer LS55 Luminescence Spectrophotometer at $25^{\circ} \mathrm{C}$. Wavelengths utilized were $485 \mathrm{nM}$ for excitation and $530 \mathrm{nM}$ for emission. The net change in FP as a function of the $\mathrm{SH} 3$ domain concentration was fit to the following equation: $\mathrm{FP}=\mathrm{FP}_{\max } \times$ [SH3] / $\left(K_{\mathrm{d}}+[\mathrm{SH} 3]\right)$, where $\mathrm{FP}_{\max }$ was the maximum polarization value at saturation and $K_{\mathrm{d}}$ was the dissociation constant of VSL12 binding to Src SH3 domain. Data analysis was carried out using LabFit software.

The binding of unlabeled Ac-VSL12 (1) to compete against Flu-VSL12 (2) in binding to the Src SH3 domain was evaluated. The initial competition screening tested the effect of $500 \mathrm{nM}$ unlabeled derivative on the binding of Flu-VSL12 to the Src SH3 domain. The concentration of Flu-VSL12 and SH3 domain were $120 \mathrm{nM}$ and $1 \mu \mathrm{M}$, respectively. Subsequently, a second round of screening was carried out with $2 \mu \mathrm{M}$ unlabeled derivative in the presence of $2 \mu \mathrm{M}$ of Src SH3 and $120 \mathrm{nM}$ of Flu-VSL12.

All newly synthesized VSL12 derivatives (3-10) were then fully evaluated in triplicate, for their binding to the Src SH3. With Flu-VSL12 at $120 \mathrm{nM}$, VSL12 and SH3 domain were used at constant concentrations of $1 \mu \mathrm{M}$. The peptides were used at concentrations of $0,0.25,0.5,1.0$, 2.0, and $4.0 \mu \mathrm{M}$. The binding buffer was $50 \mathrm{mM}$ Tris $\mathrm{pH}=8.0$. The $K_{\mathrm{d}}$ was then determined for the competing ligand by plotting the FP as a function of the increasing concentration of the unlabeled derivative and fitting the curve to the equation: $\mathrm{FP}=A \times\left([\mathrm{SH} 3]_{\mathrm{t}} \times[\text { Probe }]_{\mathrm{t}} \times K_{\mathrm{d} 2}\right) /\left(K_{\mathrm{d} 1}\right.$ $\left.\times K_{\mathrm{d} 2}+K_{\mathrm{d} 1} \times[\mathrm{Pept}]_{\mathrm{t}}+[\mathrm{SH} 3]_{\mathrm{t}} \times K_{\mathrm{d} 2}\right)$, where $K_{\mathrm{d} 1}$ is the dissociation constant of Flu-VSL12, as 
determined above and $K_{\mathrm{d} 2}$ is the dissociation constant of the unlabeled VSL12 derivative. $A$ is a conversion factor between the concentration of the probe-SH3 complex and the FP value. [SH3 $]_{t}$ and [Probe $]_{\mathrm{t}}$ were total SH3 and Flu-VSL12 concentrations. [Pept $]_{\mathrm{t}}$ is the total concentration of unlabeled competing ligand.

\section{Results and Discussion}

\subsection{Chemistry}

The presence of proline residue at the carboxy terminus of a peptide during solid-phase peptide synthesis has been associated with high levels of diketopiperazine formation [24]. Thus, the synthesis was carried out on a 2-chlorotrityl chloride resin. The bulkiness of the trityl linker minimized diketopiperazine formation during tripeptide formation.

Scheme 1 shows the synthesis of Ac-VSL12 (Ac-VSLARRPLPPLP, 1), the fluoresceinlabeled VSL12 (Fluorescein-VSLARRPLPPLP, Flu-VSL-12, 2), and the conformationally constrained peptide (3) resulted from head to tail cyclization. To synthesize compound $\mathbf{1}$ and its carboxyfluorescein derivative (2), H-Pro-2-chlorotrityl chloride resin 11 was used and the linear sequence was assembled on the resin using Fmoc/tBu solid-phase peptide synthesis methodology (Scheme 1). The Fmoc group at the end of the synthesis was removed by using piperidine (20\% $\mathrm{v} / \mathrm{v}$ ) in DMF to yield 12. Resin-attached peptide 12 was capped by using acetic anhydride in DMF and underwent cleavage and deprotection to afford 1. Alternatively, resin 12 was conjugated with the 5(6)-carboxyfluorescein in the presence of PyAOP/HOAt/DMF in DMF, which after final cleavage and deprotection gave fluorescent-labeled peptide 2 . The fluorescent probe was used for determination of the binding affinity between the Src SH3 domain and synthesized compounds.

The synthesis of conformationally constrained peptide [VSLARRPLPPLP] (3) by head to tail cyclization was performed by using resin 12. The cleavage in the presence of $\mathrm{AcOH} / \mathrm{TFE} / \mathrm{DCM}(1: 2: 7 \mathrm{v} / \mathrm{v} / \mathrm{v})$ for $1 \mathrm{~h}$ at room temperature afforded the linear protected peptide 13 with free $N$ - and $C$-terminals. Head to tail cyclization was carried out in the presence of HOAt/DIC in DMF/DCM. Deprotection with reagent $\mathrm{R}$ and purification afforded conformationally constrained peptide $\mathbf{3}$ (Scheme 1).

"Please insert Scheme 1 here."

The synthesis of diacetylated linear peptide Ac-VS $\mathrm{Ac}_{\mathrm{L}}$ ARRPLPPLP (4) is depicted in Scheme 2. Fmoc-Ser(Trt)-OH at position 2 was assembled as the building block on resinattached peptide while synthesizing the sequence of the VSL-12 on H-Pro-2-chlorotrityl resin (11). The Fmoc group was removed from the $N$-terminal to yield 14. The deprotection of the trityl group and cleavage from the resin in the presence of cocktail (TFA/DCM/TIS) (1:94:5 $\mathrm{v} / \mathrm{v} / \mathrm{v}$ ) afforded the partially protected peptide. The $N$-terminal of the peptide and side chain of serine were capped with acetyl group in the presence of acetic anhydride and DIPEA in DMF at room temperature to give 4 . Because of capped serine residue, 4 cannot be used to perform cyclization between $C$-terminal and side chain of serine.

To cyclize the peptide through $C$-terminal to side chain cyclization, Boc protected valine (Boc-Val-OH) and Fmoc-Ser(Trt)-OH were used at positions 1 and 2 while assembling the peptide on resin 11. Thus, no capping step was required before the cyclization. The deprotection of the serine side chain and cleavage from the resin were achieved by using a cleavage cocktail, 
TFA/DCM/TIS (1:94:5 v/v/v), to yield the partially protected peptide 15, which underwent cyclization in the presence of HOBt, HBTU, DIC, DIPEA in DMF/DCM $(5: 1, \mathrm{v} / \mathrm{v})$ at room temperature for $8 \mathrm{~h}$. After cyclization between $C$-terminal and side chain of serine, the final deprotection was achieved by using reagent $\mathrm{R}$ to afford compound V[SLARRPLPPLP] (5) (Scheme 2).

"Please insert Scheme 2 here."

$N$-terminal valine to side chain serine cyclization failed when 2-chlorotrityl resin was used due to simultaneous deprotection of serine side chain and cleavage of partially protected peptide from the trityl resin in one step. Because of high sensitivity of trityl resin to acid, Fmocpro-Wang resin (16) was used for the synthesis (Scheme 3). After every coupling, a small amount of resin was cleaved to monitor the progress of the reaction by confirming the molecular weight of the peptide using SELDI-TOF. The cyclization between $N$-terminal valine and the side chain of serine was not successful. $\beta$-Alanine was assembled at the $N$-terminal of linear peptide. After Fmoc-deprotection, the trityl group from the side chain of serine was deprotected using a cleavage cocktail, TFA/DCM/TIS $(1: 94: 5 \mathrm{v} / \mathrm{v} / \mathrm{v})$, to afford 17. The cyclization between free amino group of $\beta$-alanine and the side chain of serine at position 3 was carried out in the presence of HOAt, DIC, and DMF/DCM $(5: 1 \mathrm{v} / \mathrm{v})$ at room temperature for $8 \mathrm{~h}$. The final cleavage afforded $\left[{ }^{\beta}\right.$ AVS $]$ LARRPLPPLP $(6)$.

"Please insert Scheme 3 here."

The synthesis of diacetylated linear peptide Ac-VSLK $\mathrm{Ac}_{\mathrm{c}} \mathrm{RRPLPPLP}(7)$ was started using Fmoc solid-phase synthesis protocol on 2-chlorotrityl resin 11 using Fmoc-Lys(Mtt)-OH in place of alanine at position 4 (Scheme 4). After the assembly of the peptide, the Fmoc group was removed from the $N$-terminal to yield 18. Deprotection of the MTT group followed by the cleavage of the partially protected peptide from the resin was achieved in the presence of cleavage cocktail, TFA/DCM/TIS (2:93:5 v/v/v). Capping the peptide with acetic anhydride, followed by deprotection by Reagent $\mathrm{R}$ afforded the diacetylated peptide AcVSLK $_{\mathrm{Ac}}$ RRPLPPLP (7).

The synthesis of the conformationally constrained peptide VSL[KRRPLPPLP] (8) (Cterminal to side chain cyclization) was carried out using Boc-Val-OH in place of Fmoc-Val-OH at position 1 to afford 19. The Mtt group from the side chain of lysine was cleaved and the partially protected peptide was cleaved from the resin in the presence of cleavage cocktail, TFA/DCM/TIS (2:93:5 v/v/v) to yield 20 (Scheme 4). $C$-terminal to side chain cyclization was achieved in the presence of HOAt and DIC in DMF/DCM (5:1 v/v). Final deprotection afforded the conformationally constrained peptide VSL[KRRPLPPLP] (8).

"Please insert Scheme 4 here."

The synthesis of linear peptide VSLERRPLPPLP (9) and conformationally constrained peptide [VSLE]RRPLPPLP (10, $N$-terminal to side chain cyclization) is shown in Scheme 5. The linear peptide was assembled on resin 11 by using Fmoc-Glu (ODmab)-OH in the place of Fmoc-Ala-OH at position 4. Removing the Fmoc group of the $N$-terminal afforded resin-attached peptide 21. The Dmab group from the side chain of the glutamic acid was removed using 
hydrazine hydrate in DMF (2\%) to yield 22. A portion of resin-attached peptide was cleaved and deprotected to afford compound 9. Furthermore, another part of resin-attached peptide 22 underwent cyclization between $\mathrm{NH}_{2}$ group of the $N$-terminal and the side chain $\mathrm{COOH}$ group of glutamic acid residue in the presence of HOAt, DIC, and DMF/DCM (5:1 v/v). The final cleavage and deprotection afforded peptide $\mathbf{1 0 .}$

"Please insert Scheme 5 here."

\subsection{Fluorescent Polarization Binding Assay}

The binding affinities of the synthesized peptides (2-10) against the Src SH3 domain were examined and compared with the corresponding linear peptide (1) (Table 1) using a fluorescence polarization competitive assay [23]. Unlabeled linear probe $\mathbf{1}$ competed with probe 2 for binding to the Src SH3 domain resulting in the decreased FP values. Ac-VSL-12 (1) showed a $K_{\mathrm{d}}$ value of $0.34 \mu \mathrm{M}$ that was consistent with the reported value [14].

VSL-12 contains a core RPLPPLP that forms a helix upon binding with the Src SH3 domain. VSLAR flanking sequence in VSL-12 was selected from a phage library to increase the binding affinity of the core sequence [14]. There are three major interactions between the core portion of VSL-12 and the Src SH3 domain (i.e. hydrophobic, electrostatic, and hydrogen bonding interactions). Both $\mathrm{Leu}^{8}$-Pro ${ }^{9}$ and $\mathrm{Leu}^{11}-\mathrm{Pro}^{12}$ moieties bind to hydrophobic pockets containing Tyr ${ }^{90}$, Tyr ${ }^{92}, \mathrm{Tyr}^{136}$, and $\operatorname{Trp}^{118}$ of the Src SH3 domain. Additionally, $\mathrm{Arg}^{6}$ in RPLPPLP portion forms a salt bridge with $\mathrm{Asp}^{99}$ near the RT loop of the SH3 domain. The carbonyl of $\mathrm{Arg}^{6}$ in VSL-12 and the indole of $\mathrm{NH}$ of $\operatorname{Trp}^{118}$ forms a hydrogen bond. Side chain $\mathrm{NH}_{2}$ of $\mathrm{Asn}^{59}$ in the SH3 domain make an intermolecular hydrogen bond with the carbonyl of Pro $^{9}$ in the ligand. Other intermolecular hydrogen bonding interactions are formed between the carbonyl of Pro ${ }^{10}$ in the ligand and the hydroxyl of $\mathrm{Tyr}^{136}$ [14].

The corresponding conformationally constrained peptide $\mathbf{3}$, synthesized through head to tail cyclization of VSL-12, showed 10-fold weaker binding affinity $\left(K_{\mathrm{d}}=3.5 \mu \mathrm{M}\right)$ when compared with 1. Decreased binding affinity towards the Src SH3 domain by a non-linear structure $\mathbf{3}$ may be due to the loss of some of hydrophobic, hydrogen bonding, and/or electrostatic interactions between some residues in the constrained peptide and the Src SH3 domain. The folded structure in $\mathbf{3}$ may not provide appropriate locations for the side chains of amino acids, Leu-Pro and Arg, in RPLPPLP for maximal interactions with hydrophobic pockets and negatively-charged Asp ${ }^{99}$ of the Src SH3 domain.

Diacetylated peptide 4 with a capped $\mathrm{OH}$ group of serine residue at position 2 exhibited a comparable binding affinity $\left(K_{\mathrm{d}}=0.56 \mu \mathrm{M}\right)$ versus that of VSL-12, suggesting that the side chain of serine may be used for the synthesis of constrained peptides without the significant loss of binding affinity. Thus, conformationally constrained peptide 5 was synthesized through $C$ terminal cyclization with the side chain residue of serine at position 2 , and showed similar binding affinity $\left(K_{\mathrm{d}}=0.35 \mu \mathrm{M}\right)$ when compared the corresponding linear peptide 1 . These data suggest that cyclization between serine 2 in flanking residues (VSLAR) and $C$-terminal can be tolerated. Flanking residues $\mathrm{Leu}^{3}, \mathrm{Ala}^{4}$, and $\mathrm{Arg}^{5}$ of VSL-12 occupy a large pocket surrounded by $\operatorname{Trp}^{118}$, $\operatorname{Tyr}^{131}$ and RT loop of the Src SH3 domain [14]. The size of the pocket allows the cyclization with serine 2 in the flanking residues without disturbing the hydrophobic and electrostatic interactions by core RPLPPLP residues.

On the other hand, $N$-terminal cyclization with the side chain of serine residue at position 2 in flanking sequence in conformationally constrained peptide $\mathbf{6}$ decreased binding affinity $\left(K_{\mathrm{d}}\right.$ $=4.8 \mu \mathrm{M})$. These data indicate that use of $N$-terminal residue in generating conformationally 
constrained peptides as shown in peptides $\mathbf{3}$ and $\mathbf{6}$ was counterproductive, possibly due to critical interaction of $\mathrm{N}$-terminal residue valine 1 with the $\mathrm{Src} \mathrm{SH} 3$ domain. The flanking sequences increase binding affinity of the ligands to SH3 domain and in the case of 6 the cyclization between flanking residues appears to significantly affect the ability of the peptide to bind with the Src SH3 domain.

The placement of a capped lysine residue at position 4 in peptide 7 in place of alanine reduced the binding affinity $\left(K_{\mathrm{d}}=2.2 \mu \mathrm{M}\right)$. Similarly, the placement of negatively-charged glutamic acid at position 4 in peptide 9 was not beneficial $\left(K_{\mathrm{d}}=2.7 \mu \mathrm{M}\right)$. Flanking residues Ala ${ }^{4}$ of VSL-12 occupy a pocket surrounded by $\operatorname{Trp}^{118}, \mathrm{Tyr}^{131}$ and RT loop of the Src SH3 domain and replacement of the Ala with a large side chains in $\mathbf{7}$ and $\mathbf{9}$ was not tolerated. As expected cyclization of $C$-terminal to side chain of lysine residue (K4) in peptide $\mathbf{8}$ did not improve the binding affinity $\left(K_{\mathrm{d}}=2.9 \mu \mathrm{M}\right)$ possibly due to significant change in the structure for appropriate interactions with the $\mathrm{SH} 3$ domain.

Cyclization of $N$-terminal to side chain of glutamic acid residue at position 4 (E4) in peptide 10 improved the binding affinity marginally $\left(K_{\mathrm{d}}=2.2 \mu \mathrm{M}\right)$ when compared to the corresponding linear peptide 9.

Table 1. The binding affinities of peptides towards the Src SH3 domain ${ }^{\mathrm{a}}$.

\begin{tabular}{ccc}
\hline Peptide & Sequence & $\boldsymbol{K}_{\boldsymbol{d}}^{\boldsymbol{b}}$ \\
\hline VSL-12(1) & Ac-VSLARRPLPPLP & 0.34 \\
$\mathbf{3}$ & [VSLARRPLPPLP] & 3.54 \\
$\mathbf{4}$ & Ac-VS(Ac)LARRPLPPLP & 0.56 \\
$\mathbf{5}$ & V[SLARRPLPPLP] & 0.35 \\
$\mathbf{6}$ & [ ${ }^{\beta}$ AVS]LARRPLPPLP & 4.85 \\
$\mathbf{7}$ & Ac-VSLK(Ac)RRPLPPLP & 2.21 \\
$\mathbf{8}$ & VSL[KRRPLPPLP] & 2.96 \\
$\mathbf{9}$ & VSLERRPLPPLP & 2.70 \\
$\mathbf{1 0}$ & [VSLE]RRPLPPLP & 2.19 \\
\hline
\end{tabular}

${ }^{\mathrm{a}}[\mathrm{Src} \mathrm{SH} 3]=1 \mu \mathrm{M}$, [Flu-VSL12, 2] $=120 \mathrm{nM} ;{ }^{\mathrm{b}}$ In general mean of three separate determinations with a standard deviation of less than $5 \%$.

In general, these data provide structure-activity relationships for VSL-12 derivatives. The optimal binding of VSL-12 with the Src SH3 domain occur through delicate hydrophobic, electrostatic, and hydrogen bonding interactions of core and flanking residues of the ligand with specific residues of the protein when the peptide is oriented in an extended form. The Src SH3 domain binding pocket is shallow, thus the design of conformationally constrained peptides for this regulatory domain remains a challenge as residues in cyclized peptides lose some critical interactions. These results suggest that $N$-terminal cyclization reduces the binding affinity towards the Src SH3 domain compared to linear peptide 1 as shown in conformationally constrained peptides 3, 6, and 10. Thus, $N$-terminal valine 1 in VSL-12 cannot be subjected to strain for generating more potent Src SH3 domain binding ligands. Further optimization of conformationally constrained peptide $\mathbf{5}$ or generating other constrained peptides through side chain to side chain cyclization may result in producing ligands with appropriate orientation and more optimal binding affinity and stability.

\section{Acknowledgements}


We acknowledge the financial support from the American Cancer Society Grant \# RSG-07-29001-CDD. 


\section{References}

[1] S.M. Thomas, J.S. Brugge, Cellular functions regulated by Src family Kinase, Ann. Rev. Cell Div. Biol. 13 (1997) 513-609.

[2] M. Warmuth, R. Damoiseaux, U. Liu, D. Fabbro, N. Gray, Src family kinases potential targets for the treatment of human cancer and leukemia, Curr. Pharm. Des. 9 (2003) 2043-2059.

[3] T. Pawson, Protein modules and signalling networks. Nature 373 (1995) 573-580.

[4] W. Xu, S.C. Harrison, M.J. Eck, Three dimensional structure of the tyrosine kinase c-Src, Nature 385(1997) 595-602.

[5] Z. Songyang, S.E. Shoelson, M. Chaudhuri, et al; SH2 domains recognize specific phosphopeptide sequences, Cell 72 (1993) 767-778.

[6] F. Sicheri, I. Moarefi, J. Kuriyan, Crystal structure of the Src-family tyrosine kinase Hck. Nature 385 (1997) 602-609.

[7] R. Roskoski, Src kinase regulation by phosphorylation and dephosphorylation, Biochem. Biophys. Res. Commun. 331 (2005) 1-14.

[8] Z. Shen, A. Batzer, J.A. Koehler, P. Polakis, J. Schlessinger, N. B. Lydon, M. F. Moran, Evidence for SH3 domain directed binding and phosphorylation of Sam68 by Src, Oncogene, 18 (1999) 4647-4653.

[9] X. Cao, A. Tay, G.R. Guy, Y.H. Tan, Activation and association of Stat3 with Src in vSrc-transformed cell lines, Mol. Cell. Biol. 16 (1996) 1595-1603.

[10] J.C. Donaldson, P.J. Dempsey, S. Reddy, A.H. Bouton, R.J. Coffey, S.K. Hanks, Crkassociated substrate $\mathrm{p} 130(\mathrm{Cas})$ interacts with nephrocystin and both proteins localize to cell-cell contacts of polarized epithelial cells, Exp. Cell Res. 256 (2000) 168-178. 
[11] H. Yu, J.K. Chen, S. Feng, D.C. Dalgarno, A.W. Brauer, S.L. Schreiber, Structural basis for the binding of proline-rich peptides to SH3 domains, Cell 76 (1994) 933-945

[12] S. Feng, J.K. Chen, H. Yu, J.A. Simon, S.L. Schreiber, Two binding orientations forpeptides to the Src SH3 domain: development of a general model for SH3-ligand interactions, Science 266 (1994) 1241-1247.

[13] R.J. Rickles, M.C. Botfield, Xiao-Mai Zhou, P.A. Henry, J.S. Brugge, M.J. Zoller, Phage display selection of ligand residues important for Src Homology 3 domain binding specificity, Proc. Natl. Acad. Sci. USA. 92 (1995) 10909-10913.

[14] S. Feng, C. Kasahara, R.J. Rickles, S.L. Schreiber, Specific interactions outside the proline-rich core of two classes of Src homology 3 ligands, Proc. Natl. Acad. Sci. USA. 92 (1995) 12408-12415.

[15] M.R. Ferguson, X. Fan, M. Mukherjee, J. Luo, R. Khan, J.C. Ferreon, V.J. Hilser, R.E. Shope, R.O. Fox, Directed discovery of bivalent peptide ligands to an SH3 domain, Protein Sci. 13 (2004) 626-632.

[16] J.M. Humphrey, A.R. Chamberlin, Chemical synthesis of natural product peptides: Coupling methods for the incorporation of noncoded amino acids into peptides, Chem. Rev. 97 (1997) 2243-2266.

[17] A.R. Khan, J.C. Parrish, M.E. Fraser, W.W. Smith, P.A. Bartlett, M.N.G. James, Lowering the entropic barrier for binding conformationally flexible inhibitors to enzymes, Biochem. 37 (1998) 16839-16845. 
[18] W.W. Smith, P.A. Bartlett, Macrocyclic inhibitors of penicillopepsin. 3. Design, synthesis, and evaluation of an inhibitor bridged between P2 and P1, J. Am. Chem. Soc. 120 (1998) 4622-4628.

[19] J.P. Davidson, O. Lubman, T.Rose, G. Waksman, S.F. Martin, Calorimetric and structural studies of 1,2,3-trisubstituted cyclopropanes as conformationally constrained peptide inhibitors of Src SH2 domain binding, J. Am. Chem. Soc. 124 (2002) 205-215.

[20] Z. Szewczuk, P. Stefanowicz, A. Wilczynski, A. Staszewska, I.Z. Siemion, M. Zimecki, Z. Wieczorek, Immunosuppressory activity of ubiquitin fragments containing retro-RGD sequence, Biopolymers 74 (2004) 352-362.

[21] Ngugen-Hai Nam, G. Ye, G. Sun, K. Parang, Conformationally constrained peptide analogues of pTyr-Glu-Glu-IIe as inhibitor of the Src SH2 domain binding, J. Med. Chem. 47 (2004) 3131-3141.

[22] A. Kumar, G. Ye, Y. Wang, X. Lin, G. Sun, K. Parang, Synthesis and Structure-Activity Relationships of linear and conformationally constrained peptide analogues of CIYKYY as Src Tyrosine Kinase Inhibitor, J. Med. Chem. 49 (2006) 3395-3401.

[23] B.A. Lynch, K.A. Loiacono, C.L. Tiong, S.E. Adams, I.A. MacNeil, A Fluorescence Polarization Based Src-SH2 Binding Assay. Anal. Biochem. 247(1997) 77-82.

[24] R. Steinauer, P. White, Innovations and perspectives in solid phase synthesis, In R. Epton (ed.), $3^{\text {rd }}$ International Symposium. Mayflower Worldwide Ltd., Birmingham, England, 1994, pp. 689-692. 


\section{Figure and Scheme Legends}

Fig. 1. The chemical structures of the conformationally constrained and linear peptide analogues of VSL12 (1-10).

Fig. 2. SDS-PAGE of GST-Src SH3 fusion protein, stained with Coomassie Blue.

Scheme 1. Synthesis of Ac-VSL-12 (1), Flu-VSL-12 (2), and [VSLARRPLPPLP] (3) (head to tail cyclization). Reagents and reaction conditions: (i) (a) Fmoc solid-phase synthesis: coupling of Fmoc-Leu-OH, Fmoc-Pro-OH, Fmoc-Pro-OH, Fmoc-Leu-OH, Fmoc-Pro-OH, Fmoc$\operatorname{Arg}(\mathrm{Pbf})-\mathrm{OH}$, Fmoc-Arg(Pbf)-OH, Fmoc-Ala-OH, Fmoc-Leu-OH, Fmoc-Ser(OtBu)-OH, and Fmoc-Val-OH, respectively, in the presence of HBTU/DIPEA in DMF with Fmoc-deprotection (20\% v/v Piperidine in DMF) after each coupling; (ii) 20\% Piperidine in DMF; (iii) $\mathrm{Ac}_{2} \mathrm{O}$, DIPEA, DMF; (iv) reagent R, 2 h; (v) 5(6)-carboxyfluorescein, PyAOP, DIPEA, DCM/DMF(1:9 v/v), $3.5 \mathrm{~h}$; (vi) AcOH/TFE/DCM (1:2:7 v/v/v), 1h and then TFE/DCM (2:8 v/v); (vii) HOAt, DIC, DMF/DCM (5:1 v/v), 2 h.

Scheme 2. Synthesis of Ac-VS(Ac)LARRPLPPLP (4) and V[SLARRPLPPLP] (5, $C$-terminal to side chain cyclization). Reagents and reaction conditions: (i) Fmoc solid-phase synthesis: coupling of Fmoc-Leu-OH, Fmoc-Pro-OH, Fmoc-Pro-OH, Fmoc-Leu-OH, Fmoc-Pro-OH, Fmoc-Arg(Pbf)-OH, Fmoc-Arg(Pbf)-OH, Fmoc-Ala-OH, Fmoc-Leu-OH, Fmoc-Ser(OTrt)-OH, and Fmoc-Val-OH, respectively, in the presence of HBTU/DIPEA in DMF with Fmocdeprotection (20\% Piperidine in DMF) after each coupling; (ii) 20\% Piperidine in DMF; (iii) (TFA/DCM/TIS) (1:94:5 v/v/v), (iv) $\mathrm{Ac}_{2} \mathrm{O}$ DIPEA, DMF; (v) Reagent R, 2 h; (vi) Fmoc solid- 
phase synthesis: coupling of Fmoc-Leu-OH, Fmoc-Pro-OH, Fmoc-Pro-OH, Fmoc-Leu-OH, Fmoc-Pro-OH, Fmoc-Arg(Pbf)-OH, Fmoc-Arg(Pbf)-OH, Fmoc-Ala-OH, Fmoc-Leu-OH, FmocSer(OTrt)-OH, and Boc-Val-OH, respectively, in the presence of HBTU/DIPEA in DMF with Fmoc-deprotection (20\% Piperidine in DMF) after each coupling; (vii) TFA/DCM/TIS (1:94:5 v/v/v), (viii) HOBt, HBTU, DIC, DIPEA in DMF/DCM (5:1 v/v), $8 \mathrm{~h}$.

Scheme 3. Synthesis of $\left[{ }^{\beta}\right.$ AVS]LARRPLPPLP (6) ( $N$-terminal to side chain cyclization). Reagents and reaction conditions: (i) Fmoc solid-phase synthesis: coupling of Fmoc-Leu-OH, Fmoc-Pro-OH, Fmoc-Pro-OH, Fmoc-Leu-OH, Fmoc-Pro-OH, Fmoc-Arg(Pbf)-OH, Fmoc$\operatorname{Arg}(\mathrm{Pbf})-\mathrm{OH}$, Fmoc-Ala-OH, Fmoc-Leu-OH, Fmoc-Ser(Trt)-OH, Fmoc-Val-OH, and Fmoc- $\beta$ Ala-OH, respectively, in the presence of HBTU/DIPEA in DMF with Fmoc-deprotection (20\% piperidine in DMF) after each coupling; (ii) 20\% Piperidine in DMF; (iii) TFA/DCM/TIS (1:94:5 v/v/v); (iv) HOAt (4 equiv), DIC (4.5 equiv.), DMF/DCM (5:1 v/v), 8 h; (v) Reagent R.

Scheme 4. Synthesis of Ac-VSLK ${ }_{A c} R R P L P P L P ~(7)$ and VSL[KRRPLPPLP] 8 ( $C$-terminal to side chain cyclization). Reagents and reaction conditions: (i) Fmoc solid-phase synthesis: FmocLeu-OH, Fmoc-Pro-OH, Fmoc-Pro-OH, Fmoc-Leu-OH, Fmoc-Pro-OH, Fmoc-Arg(Pbf)-OH, Fmoc-Arg(Pbf)-OH, Fmoc-Lys (Mtt)-OH, Fmoc-Leu-OH, Fmoc-Ser(OtBu)-OH, and Fmoc-Val$\mathrm{OH}$, respectively, in the presence of HBTU/DIPEA in DMF with Fmoc-deprotection (20\% Piperidine in DMF) after each coupling; (ii) 20\% Piperidine in DMF; (iii) TFA/DCM/TIS (2:93:5 v/v/v); (iv) $\mathrm{Ac}_{2} \mathrm{O}$, DIPEA, DMF; (v) Reagent R, 2 h; (vi) Fmoc solid-phase synthesis: Fmoc-Leu-OH, Fmoc-Pro-OH, Fmoc-Pro-OH, Fmoc-Leu-OH, Fmoc-Pro-OH, Fmoc-Arg(Pbf)$\mathrm{OH}$, Fmoc-Arg(Pbf)-OH, Fmoc-Lys (Mtt)-OH, Fmoc-Leu-OH, Fmoc-Ser(OtBu)-OH, and Boc- 
Val-OH, respectively, in the presence of HBTU/DIPEA in DMF with Fmoc-deprotection (20\% Piperidine in DMF) after each coupling; (vii) HOAt, DIC, DMF/DCM (5:1 v/v), 8 h.

Scheme 5. Synthesis of VSLERRPLPPLP (9) and [VSLE]RRPLPPLP (10, $N$-terminal to side chain cyclization): (i) (a) Fmoc solid-phase synthesis: coupling of Fmoc-Leu-OH, Fmoc-ProOH, Fmoc-Pro-OH, Fmoc-Leu-OH, Fmoc-Pro-OH, Fmoc-Arg(Pbf)-OH, Fmoc-Arg(Pbf)-OH, Fmoc-Glu(ODmab)-OH, Fmoc-Leu-OH, Fmoc-Ser(OtBu)-OH, and Fmoc-Val-OH, respectively, in the presence of HBTU/DIPEA in DMF with Fmoc-deprotection (20\% Piperidine in DMF) after each coupling; (ii) $20 \%$ Piperidine in DMF; (iii) hydrazine hydrate in DMF $(2 \%, 3 \times 25$ mL), 10 min; (iv) HOAt, DIC, DMF/DCM (5:1 v/v), 12 h; (v) Reagent R, $2 \mathrm{~h}$. 